\title{
Pseudo-hemorrhagic region formation in pancreatic neuroendocrine tumors is a result of blood vessel dilation followed by endothelial cell detachment
}

\author{
ZAI WANG ${ }^{1}$, LIANG PENG ${ }^{1}$, YU-LI SONG ${ }^{2}$, SHIQING XU ${ }^{1}$, ZHAN HUA $^{3}$, NI FANG ${ }^{4}$, MIN ZHAI $^{1}$, \\ HONGLIN LIU ${ }^{1}$, QING FANG ${ }^{1}$, TINGTING DENG ${ }^{1}$, WENJIAN ZHANG ${ }^{1}$, YUAN-JIA CHEN ${ }^{2}$ and JINNING LOU ${ }^{1}$ \\ ${ }^{1}$ Institute of Clinical Medical Sciences, China-Japan Friendship Hospital, Chaoyang, Beijing 100029; \\ ${ }^{2}$ Department of Gastroenterology, Peking Union Medical College Hospital, Peking Union Medical College, \\ Chinese Academy of Medical Sciences, Beijing 100730; ${ }^{3}$ Department of General Surgery, China-Japan Friendship Hospital, \\ Chaoyang, Beijing 100029; ${ }^{4}$ Wangjing Hospital, China Academy of Chinese Medical Sciences, Beijing 100102, P.R. China
}

Received April 26, 2016; Accepted July 7, 2017

DOI: $10.3892 / 01.2018 .7840$

\begin{abstract}
Aberrant blood vessel formation and hemorrhage may contribute to tumor progression and are potential targets in the treatment of several types of cancer. Pancreatic neuroendocrine tumors (PNETs) are highly vascularized, particularly when they are well-differentiated. However, the process of vascularization and endothelial cell detachment in PNETs is poorly understood. In the present study, 132 PNET clinical samples were examined and a special type of hemorrhagic region was observed in $\sim 30 \%$ of the samples regardless of tumor subtype. These hemorrhagic regions were presented as blood-filled caverns with a smooth boundary and were unlined by endothelial cells. Based on the extensive endothelial cell detachment observed in the clinical samples, the formation process of these blood-filled caverns was hypothesized. Blood vessel dilation followed by detachment of endothelial cells from the surrounding tumor tissue was speculated. This was further supported using an INS-1 xenograft insulinoma model. As the formation process was distinct from the typical diffusive hemorrhage, it was named 'pseudo-hemorrhage'. Furthermore, it was demonstrated that epithelial (E-) cadherin and $\beta$-catenin were overexpressed in tumor cells surrounding these pseudo-hemorrhagic regions. Therefore, even though no statistically significant association of pseudo-hemorrhage with clinical features (metastasis or disease recurrence) was identified, the high levels of E-cadherin and $\beta$-catenin expression may suggest that a number of features of normal islet cells are retained.
\end{abstract}

Correspondence to: Dr Zai Wang, Institute of Clinical Medical Sciences, China-Japan Friendship Hospital, 2 Yinghua East Road, Chaoyang, Beijing 100029, P.R. China

E-mail: wzai_163pass@163.com

Key words: pancreatic neuroendocrine tumor, hemorrhage, endothelial cells, INS-1 cells, epithelial cadherin, $\beta$-catenin

\section{Introduction}

Robust angiogenesis and aberrant blood vessel formation are common characteristics of tumors and are considered promising therapeutic targets for numerous types of cancer $(1,2)$. Owing to the aberrant tumor vasculature, intratumoral hemorrhage is a common feature of malignancy. The intensity of hemorrhage has been identified to be associated with the histological grade and stage of tumors (3). The leakiness of tumor vessels promotes the extravasation of blood cells and plasma proteins, as well as metastasis via the bloodstream (4-7). Therefore, intratumoral hemorrhage serves a critical role in prognosis.

Regarding the underlying molecular mechanism of intratumoral hemorrhage, it has been suggested that the interstitial blood may result from the capillary sprouting, termed angiogenesis, which is stimulated by vascular endothelial growth factor A (VEGFA) secreted by tumor cells. Blood escaping the microvasculature may also be a normal feature resembling the granulation tissue (5). Intratumoral hemorrhage has also been attributed to the defective endothelial lining of tumor vessels, which may be disorganized, loosely connected, branched, overlapping or sprouting. Opening between these abnormal endothelial cells may permit blood leakage (5). The intratumoral hemorrhage may range from scattered blood cells to blood lakes, which are relatively large regions of extravasated erythrocytes (8-11).

Pancreatic islets are richly vascularized compartments with a dense network of capillaries. Although they only account for $1 \%$ of the pancreatic mass, they receive between 7 and $10 \%$ of the total pancreatic blood flow (12). The endocrine cells release VEGFA, angiopoietin-2 and insulin, promoting their proliferation (13). It has been documented that endocrine tumors are highly vascularized (14), particularly the well-differentiated pancreatic neuroendocrine tumors (PNETs) (15). Therefore, computed tomography angiography is used for diagnosing and localizing small PNETs (16) and drugs targeting VEGF signaling are used for PNET treatment. Sunitinib has been approved for the treatment of unresectable or metastatic progressive well-differentiated PNETs (17). However, the 
process of tumor vascularization in PNETs remains unclear. Interestingly, the microvascular density has been identified to be negatively associated with tumor progression and the proliferation index of endothelial cells (15). These observations suggest a unique mechanism for PNET vascularization.

In the present study, hemorrhage was investigated in 132 PNET clinical samples. In $\sim 30 \%$ of these samples, regardless of the tumor subtype, a special type of hemorrhagic region with a smooth boundary unlined by endothelial cells, was observed. On the basis of observations in clinical samples and the INS-1 xenograft tumor model, the unique formation steps of these blood-filled caverns were predicted and the relevant implications are discussed.

\section{Materials and methods}

Clinical samples. The present study was approved by the Scientific Ethics Committee of the Peking Union Medical College Hospital (Beijing, China). Participants provided written informed consent prior to participation. In total, 55 males and 77 females, aged from 14 to 74 (mean age, 45.09), were recruited from January 1998 to December 2010 in the present study. Pathological sections of PNETs with hematoxylin and eosin (H\&E) staining were collected and preserved in the Peking Union Medical College Hospital. Patients were followed up every year and recurrence or metastasis was recorded.

Cell culture. Rat insulinoma INS-1 cells were kindly provided by Dr. Haiyan Wang from Division of Clinical Biochemistry, Geneva University Medical Center (Geneva, Switzerland). INS-1 cells were cultured in RPMI-1640 medium (Gibco; Thermo Fisher Scientific, Inc., Waltham, MA, USA) containing $11.2 \mathrm{mM}$ glucose and supplemented with $10 \%$ fetal calf serum (FCS; Biological Industries Israel BeitHaemek, Kibbutz-BeitHaemek, Israel), $50 \mu \mathrm{M}$ 2-mercaptoethanol, $10^{5} \mathrm{U} / 1$ penicillin and $100 \mathrm{mg} / 1$ streptomycin at $37^{\circ} \mathrm{C}$ with $5 \% \mathrm{CO}_{2}$.

Xenograft tumor models. The Animal Studies Committee of the China-Japan Friendship Hospital (Beijing, China) approved the animal studies, which were conducted according to the Principles of Laboratory Animal Care. A total of 6 6-8-week-old female nude mice (Charles River Laboratories, Beijing, China) weighing $\sim 20 \mathrm{~g}$ were used in the model. Mice were maintained under specific-pathogen-free conditions at room temperature (between $20-24^{\circ} \mathrm{C}$ ), with humidity between $35-55 \%$, in a $12 / 12 \mathrm{~h}$ light/dark cycle, with food and water ad libitum. INS-1 cells $\left(1 \times 10^{6}\right.$ in $100 \mu 1$ FCS-free culture medium) were subcutaneously injected into the back of the mice and the glycemic level was monitored. Following 2-3 weeks, when the glycemic level was $<3.9$, each mouse were euthanized by the intraperitoneal injection of $0.1 \mathrm{ml}$ of $200 \mathrm{mg} / \mathrm{ml}$ pentobarbitone sodium and tumors with diameters between 0.53 and $0.77 \mathrm{~cm}$ were collected for histological examination.

$H \& E$, periodic acid-Schiff $(P A S)$ and Picro Sirius red staining. INS-1 tumors were fixed in $4 \%$ paraformaldehyde (PFA)/PBS at $4^{\circ} \mathrm{C}$ overnight and embedded in paraffin. The slides with $5 \mu \mathrm{m}$ in thickness were rehydrated and stained with Harris's $\mathrm{H}$ for $10 \mathrm{~min}$ and then with an EY solution for an additional $5 \mathrm{~min}$. Polysaccharide staining was performed using the PAS staining kit (BasoDiagnostics Inc., Zhuhai, China). For connective tissue staining, the slides were rehydrated and stained with Harris's $\mathrm{H}$ for $10 \mathrm{~min}$, washed in tap water, stained with Picro Sirius red (Sigma Aldrich; Merck KGaA, Darmstadt, Germany) for $1 \mathrm{~h}$ and finally washed in acidified water. The slides were observed under a light microscope at magnifications of $x 40-x 400$.

Immunohistochemistry/immunofluorescence. INS-1 tumors were fixed in $4 \%$ PFA/PBS for $2 \mathrm{~h}$ at $4^{\circ} \mathrm{C}$, cryoprotected in a $30 \%$ sucrose/PBS solution at $4^{\circ} \mathrm{C}$ overnightand then embedded in Tissue-Tek ${ }^{\circledR}$ O.C.T. compound (version E, Sakura Finetek USA Inc., Radnor, PA, USA) and preserved at $-80^{\circ} \mathrm{C}$. For frozen sections, the samples were pre-warmed in $-20^{\circ} \mathrm{C}$ for $30 \mathrm{~min}$, and then cut into $8 \mu \mathrm{m}$ sections. The primary antibodies used were: Anti-mouse cluster of differentiation 31 (CD31) (rat, 1:50, cat. no., 553370, BD Biosciences, Franklin Lakes, NJ, USA), anti-epithelial (E-) cadherin (mouse, 1:100, cat. no., 610181, BD Biosciences), anti- $\beta$-catenin (mouse, 1:100, cat. no., 610154, BD Biosciences), anti-insulin (rabbit, 1:200, cat. no., sc-9168, Santa Cruz Biotechnology, Inc., Dallas, TX, USA) and anti-laminin (rabbit, 1:100, cat. no., AB-19012, EMD Millipore, Billerica, MA, USA). The samples were incubated with the primary antibodies at $4^{\circ} \mathrm{C}$ overnight. For immunohistochemistry, anti-rat (cat. no., PV-6004, ready to use, OriGene Technologies, Inc., Beijing, China) and anti-rabbit (cat. no., PV-6001, ready to use, OriGene Technologies, Inc.) kits were applied for the secondary antibody incubation and detection procedures, according to the protocols of the manufacturer. The samples were incubated with the secondary antibodies for $30 \mathrm{~min}$ at room temperature (RT). For immunofluorescence, Alex Fluor $^{\circledR} 555$ donkey anti-mouse (1:400, cat. no., A-31570, Invitrogen; Thermo Fisher Scientific, Inc.) and Alex Fluor ${ }^{\circledR}$ 488 donkey anti-rabbit (1:400, cat. no., A-21206, Invitrogen) were used as secondary antibodies and applied to the samples for $2 \mathrm{~h}$ at RT. Fluorescence images were captured by Leica DM4000B fluorescence microscope with magnification, $\mathrm{x} 200$.

Statistical analysis. To determine the diameter of the blood-filled caverns unlined by endothelial cells, five typical blood-filled caverns were randomly selected in each of the 16 clinical slides and their diameter was determined using Photoshop ${ }^{\circledR}$ version 6.0 (Adobe Systems Inc., San Jose, CA, USA). For the association of the occurrence of these caverns with other clinicopathological features a $\chi^{2}$ test was used to examine the sampling distribution of the statistical hypothesis. Additionally, a Student's t-test was performed to compare the onset age between two different groups. $\mathrm{P}<0.05$ was considered to indicate a statistically significant difference.

\section{Results}

Blood-filled caverns unlined by endothelial cells exist in $\sim 30 \%$ of PNET clinical samples. A total of 132 PNET pathological samples, including 98 insulinoma cases, 3 glucagonoma, 9 gastrinoma and 22 non-functional PNETs, were examined. In addition to dilated blood vessels and scattered hemorrhagic regions, which are usually common in other types of tumors as well, a special type of hemorrhage was observed in $\sim 30 \%$ 

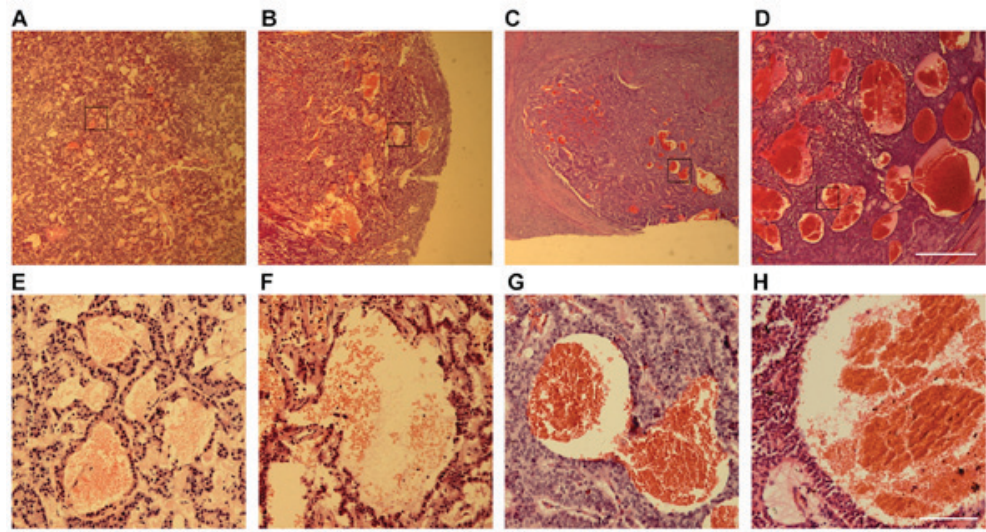

Figure 1. Blood-filled caverns unlined by endothelial cells are observed in PNET clinical samples. Hematoxylin and eosin staining images of several PNET samples: (A and E) Insulinoma, (B and F) glucagonoma, (C and G) gastrinoma and (D and H) non-functional PNET. (E-H) Higher magnification of the boxed areas in (A-D). Scale bars for (A) to (D), $1 \mathrm{~mm}$; and for (E) to (H), $50 \mu \mathrm{m}$. PNET, pancreatic neuroendocrine tumors.
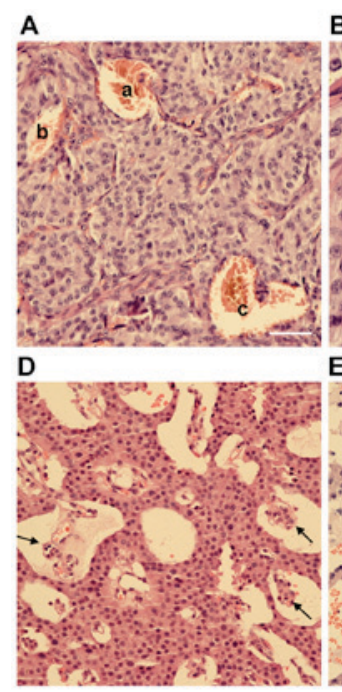

$B$

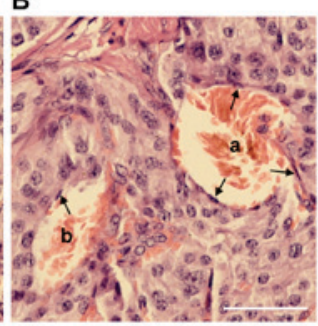

E

C

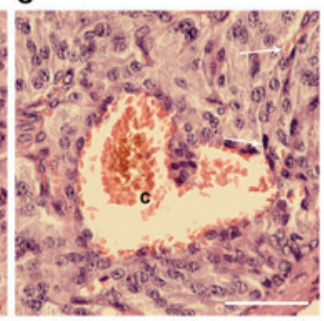

$\mathrm{F}$


Figure 2. Pancreatic neuroendocrine tumors are characterized by endothelial cell detachment. (A-C) H\&E staining of an insulinoma sample with blood-filled caverns unlined and lined by endothelial cells. (B and C) Higher magnification of blood-filled caverns presented in (A). a, Blood-filled cavern lined by endothelial cells; b, blood-filled cavern partially lined by endothelial cells; c, blood-filled cavern unlined by endothelial cells linked to normal vasculature (white arrows). (D and E) H\&E staining of two different insulinoma samples with endothelial cells detached from the surrounding tumor cells. (F) H\&E staining of a gastrinoma sample with endothelial cells detached from the surrounding tumor cells. The boxed area is presented at a 2-fold higher magnification in the lower left corner. Endothelial cells are indicated by arrows and the filamentous cell-cell connections are indicated by arrowheads. Scale bar, $25 \mu \mathrm{m}$. H\&E, hematoxylin and eosin.

of the samples tested, regardless of the tumor subtype (Fig. 1). These hemorrhagic regions were presented as blood-filled caverns with a smooth boundary and were unlined by endothelial cells. Their size varied from $<100 \mu \mathrm{m}$ to $1.32 \mathrm{~mm}$ as observed in a non-functional PNET sample (Fig. 1D).

To investigate whether the blood-filled caverns had any clinical significance, their association with several clinicopathological features was examined. However, no statistically significant association with the tumor subtype, presence of metastasis, disease recurrence, patient sex or age of onset was observed (Table I). This suggests that blood-filled caverns unlined by endothelial cells may present a common feature of PNETs.

Extensive endothelial cell detachment is present in clinical PNET samples. In certain PNET clinical samples, it was observed that not every blood filled-cavern was unlined by endothelial cells. By contrast, a number of them were partially lined by endothelial cells. In certain cases, caverns unlined or (partially) lined with endothelial cells were observed in the same tumor sample (Fig. 2A-C). In addition, the blood filled-caverns unlined by endothelial cells were associated with blood vessels lined by endothelial cells (Fig. 2C). In certain blood-filled caverns, the endothelial cells were detached from the peripheral tumor cells (Fig. 2D-F). On the basis of these observations, it was hypothesized that these blood-filled caverns, which were unlined by endothelial cells, were generated by the blind ends of dilated blood vessels lined by endothelial cells. Further dilation of the endothelial cells may cause detachment from the surrounding tumor cell layers and subsequent direct contact of blood cells with the lined tumor tissue. Morphologically, as the blood cells were mainly reserved within the original endothelial caverns and not disseminated into the tumor tissue, their shape was retained. 
Table I. PNETs with or without blood-filled caverns unlined by endothelial cells.

\begin{tabular}{|c|c|c|c|c|c|c|c|c|c|}
\hline \multirow[b]{2}{*}{$\begin{array}{l}\text { Tumor } \\
\text { type }\end{array}$} & \multirow[b]{2}{*}{$\begin{array}{c}\text { Total } \\
\mathrm{n}\end{array}$} & \multicolumn{4}{|c|}{$\begin{array}{l}\text { With blood-filled caverns } \\
\text { unlined by endothelial cells }\end{array}$} & \multicolumn{4}{|c|}{$\begin{array}{l}\text { Without blood-filled caverns } \\
\text { unlined by endothelial cells }\end{array}$} \\
\hline & & $\mathrm{n}(\%)$ & $\begin{array}{l}\text { Malignancy } \\
\qquad \%)\end{array}$ & Male (\%) & $\begin{array}{l}\text { Mean } \pm \text { SD } \\
\text { age, years }\end{array}$ & $\mathrm{n}(\%)$ & $\begin{array}{l}\text { Malignancy } \\
\qquad \%)\end{array}$ & Male $(\%)$ & $\begin{array}{c}\text { Mean } \pm \text { SD } \\
\text { age, years }\end{array}$ \\
\hline INS & 98 & $26(26.5)$ & $1(3.8)$ & $17(65.4)$ & $46.2 \pm 12.4$ & $72(73.5)$ & $3(5.8)$ & $26(36.1)$ & $45.8 \pm 16.1$ \\
\hline GLU & 3 & $2(66.7)$ & $1(50)$ & $1(100)$ & 40 & $1(33.3)$ & $1(100)$ & $0(0)$ & 51 \\
\hline GAS & 9 & $4(44.4)$ & $4(100)$ & $1(25)$ & $43.2 \pm 8.0$ & $5(55.6)$ & $5(100)$ & $2(40)$ & $47.4 \pm 13.6$ \\
\hline NF & 22 & $7(31.8)$ & $3(42.9)$ & $2(28.6)$ & $38.6 \pm 16.1$ & $15(68.2)$ & $4(26.7)$ & $6(40)$ & $42.9 \pm 12.1$ \\
\hline $\mathrm{F}$ & 110 & $32(29.1)$ & $6(18.8)$ & $19(59.4)$ & $45.5 \pm 11.6$ & $78(70.9)$ & $9(11.5)$ & $28(35.9)$ & $45.9 \pm 15.7$ \\
\hline Total & 132 & $39(29.5)$ & $9(23.1)$ & $21(53.8)$ & $44.2 \pm 12.6$ & $93(70.5)$ & $13(14.0)$ & 34 (36.6) & $45.5 \pm 15.2$ \\
\hline
\end{tabular}

Malignancy was defined as metastasis or recurrence. PNETs, pancreatic neuroendocrine tumors; INS, insulinoma; GLU, glucagonoma; GAS, gastrinoma; NF, non-functional PNETs; F, functional PNETs (including insulinoma, glucagonoma and gastrinoma); SD, standard deviation.
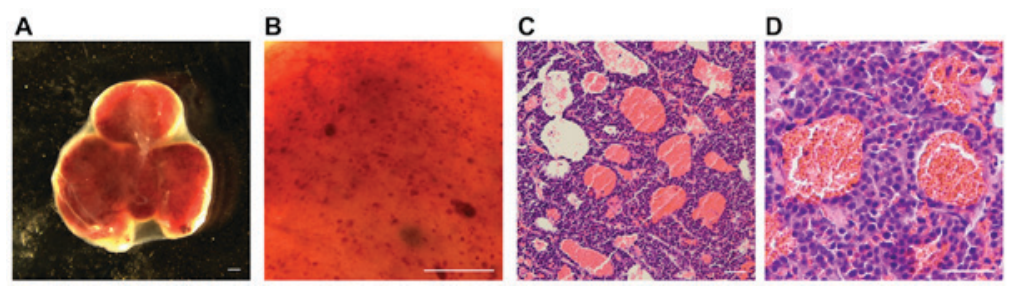

Figure 3. Blood-filled caverns unlined by endothelial cells generated in an INS-1 xenograft insulinoma model. A total of $10^{6}$ INS-1 cells were subcutaneously injected into nude mice. Xenograft insulinoma tumors were harvested 2-3 weeks later. (A and B) An insulinoma tumor observed under a stereomicroscope. (A) The tumor has a bloody appearance and intact envelope. (B) Multiple hemorrhagic spots are observed under higher magnification. Scale bar, $500 \mu \mathrm{m}$. (C and D) Hematoxylin and eosin staining of paraffin slides of INS-1 tumors. (C) Numerous blood-filled caverns can be observed in the slide. (D) The blood-filled caverns are unlined by endothelial cells as presented in higher magnification. Scale bar, $50 \mu \mathrm{m}$.
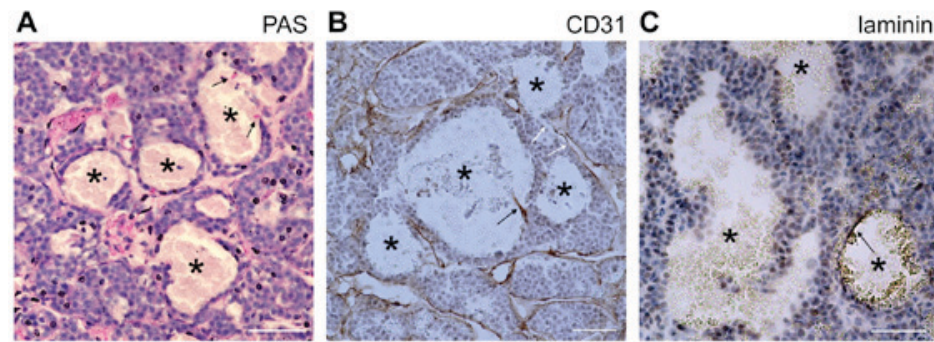

Figure 4. Blood-filled caverns unlined by endothelial cells in INS-1 tumors are distinct from vasculogenic mimicry. (A) PAS staining of INS-1 tumors. (B) CD31 staining of INS-1 tumors. PAS and CD31 staining was positive for normal blood vessels and negative for tumor cells lining the blood-filled caverns unlined by endothelial cells (marked by asterisks). Signals of endothelial cells are marked by black arrows. Certain blood-filled caverns were directly linked to normal vasculature (white arrows). (C) Laminin staining of INS-1 tumors. Laminin staining was negative in the internal face of the lining tumor cells. Only a fragment of laminin-positive staining was able to be observed in a specific blood-filled cavern (arrow). Scale bar, $50 \mu \mathrm{m}$. PAS, periodic acid-Schiff.

Blood-filled cavern formation in an INS-1 xenograft mouse model. To further investigate the development of these blood-filled caverns in PNETs, a xenograft tumor model was generated using INS-1 cells derived from X-ray-induced rat insulinoma (18). A total of $10^{6}$ INS-1 cells were subcutaneously injected into nude mice. Tumors were formed in the subsequent 2-3 weeks and the mice developed hypoglycemia, which was lethal if no treatment was provided. Abundant blood-filled caverns with a regular shape were observed within the tumors (Fig. 3A). The largest in size were able to be observed as blood spots under a stereomicroscope (Fig. 3B). The majority of the blood-filled caverns in the INS-1 tumors was unlined by endothelial cells (Fig. 3C and D) and stained negative for CD31, PAS and laminin (Fig. 4); indicating that they lack not only the surrounding endothelial cells, but also the laminin basement membrane which normally separates the endothelial from the tumor cells. Furthermore, this result suggests that the surrounding tumor cells that stained negative for PAS and laminin were distinct from the endothelial-like cells, generated through vasculogenic mimicry.

In certain endothelial-unlined blood-filled caverns, CD31-positive cell debris (Fig. 4B) or a fragment of laminin basement membrane was observed (Fig. 4C), suggesting the 
A

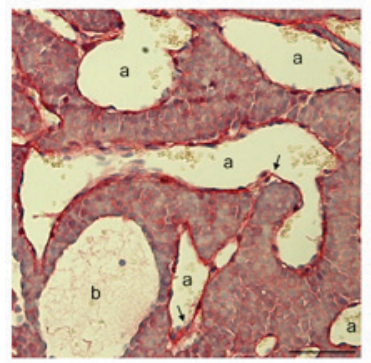

B

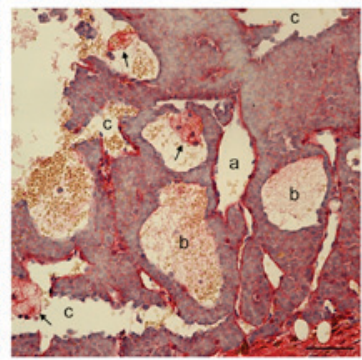

C

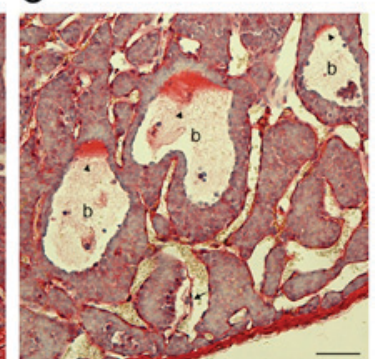

Figure 5. Blood-filled caverns unlined by endothelial cells are generated from blood vessel dilation followed by endothelial detachment as demonstrated by Sirius red staining of INS-1 tumors. (A-C) Represent different sites in the same slide. (A) Certain endothelial cells were not connected (arrows) with adjacent tumor cells in dilated blood vessels or blood-filled caverns (marked as a). (B) Detached endothelial cells formed a cluster (arrows) in blood-filled caverns unlined by endothelial cells (marked as b). (C) In specific blood-filled caverns (marked as c), collagen deposition was observed in a particular site of the lakeside (arrowheads). Endothelial cell detachment (arrow) was also observed. Scale bar, $50 \mu \mathrm{m}$.
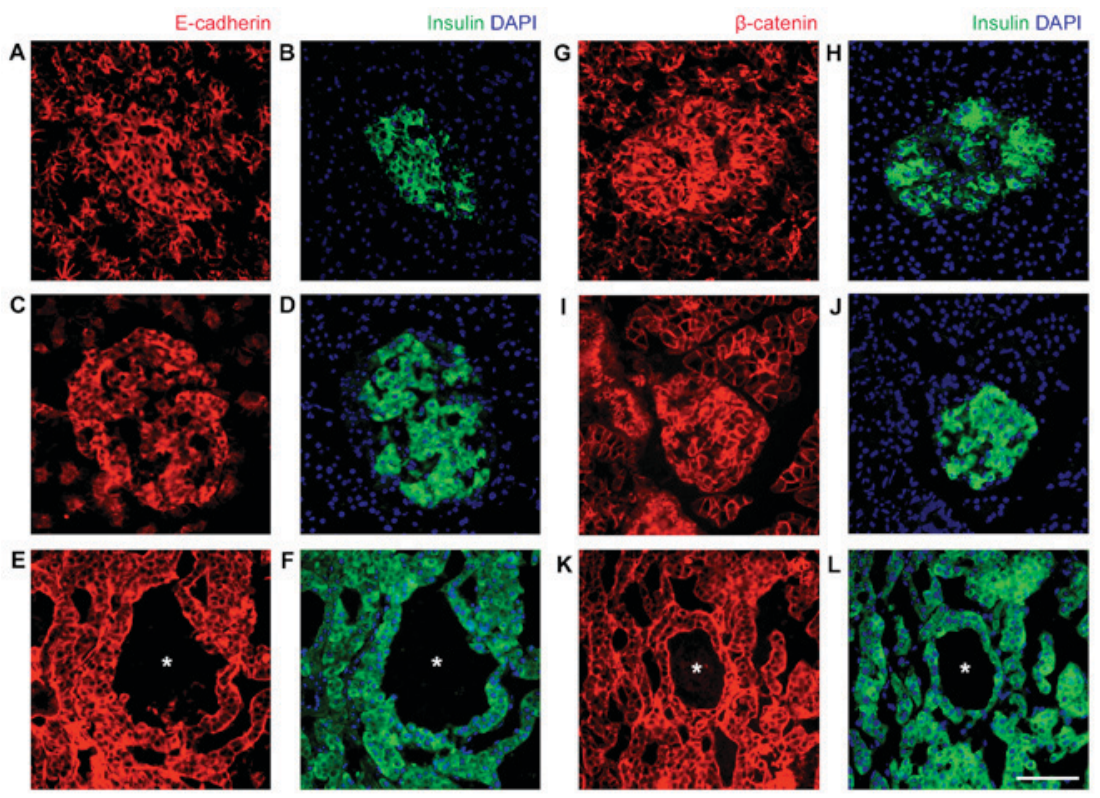

Figure 6. Expression of epithelial markers in normal islets and INS-1 xenograft tumors. (A-F) Expression of E-cadherin (red) and insulin (green) examined by immunofluorescence. (A and B) Normal human pancreas, (C and D) rat pancreas and (E and F) INS-1 xenograft tumors. Insulin and DAPI (blue) staining serves as an indication of islets and insulinoma cells, respectively. (G-L) Expression of $\beta$-catenin (red) and insulin (green) examined by immunofluorescence. ( $\mathrm{G}$ and $\mathrm{H}$ ) Normal human pancreas, (I and $\mathrm{J}$ ) rat pancreas and (K and L) INS-1 xenograft tumors. Insulin and DAPI (blue) staining serves as an indication of islets and insulinoma cells, respectively. Blood-filled caverns unlined by endothelial cells are indicated by asterisks in INS-1 tumors. Scale bar, $50 \mu \mathrm{m}$. E-cadherin, epithelial cadherin.

previous existence of endothelial cells. In addition, certain blood-filled caverns were directly linked to normal vasculature (Fig. 4B), suggesting that they were not isolated hemorrhagic regions. Using Sirius red staining to detect collagen expression in blood vessels, endothelial cells in different formation stages of blood-filled caverns were observed. In specific dilated blood vessels, the endothelial cells were almost detached from the adjacent tumor cells, in other blood-filled caverns the detached endothelial cells formed a cluster and in blood-filled caverns unlined by endothelial cells collagen deposition were only observed in specific sites of the lakeside (Fig. 5). The results of the INS-1 xenograft insulinoma model supported the hypothesis that the blood-filled caverns unlined by endothelial cells were generated from blood vessel dilation followed by endothelial detachment. This process is distinct from the traditional 'hemorrhage', which is defined as blood cell leakage from damaged vasculature resulting in irregular and diffusive hemorrhage in tumor tissue. Therefore, it is proposed that this specific type of hemorrhage is named 'pseudo-hemorrhage'.

Intact cell-cell adhesion between tumor cells may be responsible for the formation of pseudo-hemorrhagic regions. The final question asked in the present study was why the blood cells did not infiltrate into the tumor tissue, and were contained within the originally formed caverns, resulting in their shape remaining intact. Islet cells have an epithelial origin and the cell-cell junctional protein content is associated with $\beta$-cell maturation $(19,20)$. As E-cadherin and $\beta$-catenin were highly expressed in normal human and rat islets (Fig. 6), it was speculated that the cell-cell connection of islet tumor cells prevents blood cell infiltration. As anticipated, E-cadherin and $\beta$-catenin were highly expressed and localized at cell-cell junctions of INS-1 tumor cells (Fig. 6). Therefore, even though no association of pseudo-hemorrhage with clinical features 
was identified, the underlining expression of E-cadherin and $\beta$-catenin suggests that normal islet cell features are retained.

\section{Discussion}

In the present study, a special type of hemorrhagic region was observed in $\sim 30 \%$ of the PNET samples examined regardless of the tumor subtype. These regions exhibited a smooth boundary, were unlined by endothelial cells and were distinct from the irregular hemorrhage as this is traditionally described. This type of hemorrhage was also observed in an INS-1 xenograft tumor model. On the basis of observations in clinical samples and INS-1 tumor models, the unique formation steps of these hemorrhagic regions were predicted. They involved dilation of blood vessels followed by detachment of endothelial cells from the tumor tissue. This was distinct from vasculogenic mimicry, or hemorrhage defined as blood cell leakage from damaged vasculature. Therefore, this type of hemorrhage was termed 'pseudo-hemorrhage'.

Regarding the clinical significance of pseudo-hemorrhage, no statistically significant association was identified with tumor subtype, presence of metastasis, disease recurrence, patient sex or age of onset. In previous studies with genetically modified mice, including a RIP-TAG2 insulinoma model (21) and aprohormone convertase 2-knockout glucagonoma model (22), similar hemorrhagic regions resembling blood lakes have also been reported. This suggests that this type of hemorrhagic region may be a prominent feature of islet tumors. In a previous study, using RIP-TAG2 mice injected with Monastral blue, it was demonstrated that the blood lakes were not connected to the bloodstream (21). In the present study, clear morphological evidence was provided suggesting that the pseudo-hemorrhagic regions, in clinical samples and INS-1 tumors, are connected to the vascular channels. This is consistent with the hypothesis that the pseudo-hemorrhagic regions are formed through endothelial detachment.

The interaction between pancreatic islet cells and endothelial cells is a major area of interest. In normal pancreatic islets, the endocrine cells are connected to the capillary network, and molecule exchange occurs between islet cells and the bloodstream through fenestrae existing in endothelial cells $(23,24)$. These are pores $\sim 100 \mathrm{~nm}$ covered by a permeable diaphragm formed by the fusion of apical and basolateral plasma membranes. It has been demonstrated that islets contain $\sim 5-10$-fold more fenestrae than exocrine tissue $(24,25)$. However, how the endocrine cells induce fenestrae and whether the weak connection between endocrine and endothelial cells is associated with fenestrae are poorly understood. It is worthy of mention that endothelial detachment following islet transplantation has been reported. It has been demonstrated that in isolated islets 6 weeks following transplantation, $\sim 80 \%$ of the grafted microvessels contained no endothelial cell lining (26). In the INS-1 xenograft tumor model and PNET clinical samples used in the present study, extensive endothelial detachment from tumor cells was observed while the tumor cell-cell adhesion remained intact. It was therefore hypothesized that the vulnerability of islet endothelial cells or the relatively weak linkage between endothelial cells/basement membranes and tumor cells was associated with the special features of islet endocrine cells; and the underlying molecular mechanism requires further investigation.

Liver metastasis occurs frequently in PNETs and epithelial-mesenchymal transition (EMT) serves a critical role in tumor cells entering the bloodstream, particularly when intratumoral hemorrhage occurs $(6,7,27)$. However, tumor cells tightly surrounding the pseudo-hemorrhagic regions suggest a limited possibility of EMT. The epithelial markers E-cadherin and $\beta$-catenin serve an important role in the localization of tight junction molecules. It has been demonstrated that E-cadherin deficiency in stratified skin epithelium may result in failure of water retention $(28,29)$. In the present study, it was demonstrated that E-cadherin and $\beta$-catenin were highly expressed and localized at the cell-cell junctions of INS-1 tumor cells surrounding the pseudo-hemorrhagic regions. This may prevent the infiltration of blood cells into tumor tissue and retain them within the original caverns. Therefore, although no statistically significant association of pseudo-hemorrhage with any clinicopathological feature was identified, the underlying expression of E-cadherin and $\beta$-catenin suggests that islet cells may have an epithelial origin.

\section{Acknowledgements}

The present study was supported by the National Nature Science Foundation of China (grant nos. 81302334 and 81370873), the China-Japan Friendship Hospital Youth Science and Technology Excellence Project (grant nos. 2015-QNYC-B-06 and 2014-QNYC-A-05) and the National Basic Research Program of China (grant no. 2012CB966402). Dr Peigang Wang (Capital Medical University, Beijing, China) is thanked for his contribution and critical comments to the present study.

\section{References}

1. Ferrara N, Hillan KJ, Gerber HP and Novotny W: Discovery and development of bevacizumab, an anti-VEGF antibody for treating cancer. Nat Rev Drug Discov 3: 391-400, 2004.

2. Arjaans M, Schröder CP, Oosting SF, Dafni U, Kleibeuker JE and de Vries EG: VEGF pathway targeting agents, vessel normalization and tumor drug uptake: From bench to bedside. Oncotarget 7: 21247-2158, 2016.

3. Daldrup H, Shames DM, Wendland M, Okuhata Y, Link TM, Rosenau W, Lu Y and Brasch RC: Correlation of dynamic contrast-enhanced MR imaging with histologic tumor grade: Comparison of macromolecular and small-molecular contrast media. AJR Am J Roentgenol 171: 941-949, 1998.

4. Dvorak HF, Nagy JA, Dvorak JT and Dvorak AM: Identification and characterization of the blood vessels of solid tumors that are leaky to circulating macromolecules. Am J Pathol 133: 95-109, 1988.

5. Van den Brenk HA, Crowe M, Kelly H and Stone MG: The significance of free blood in liquid and solid tumours. Br J Exp Pathol 58: 147-159, 1977.

6. Ellis LM and Fidler IJ: Angiogenesis and metastasis. Eur J Cancer 32A: 2451-2460, 1996.

7. Liotta LA: Cancer cell invasion and metastasis. Sci Am 266: 54-59, 1992.

8. Schechter JE, Felicio LS, Nelson JF and Finch CE: Pituitary tumorigenesis in aging female C57BL/6J mice: A light and electron microscopic study. Anat Rec 199: 423-432, 1981.

9. Liwnicz BH, Wu SZ and Tew JM Jr: The relationship between the capillary structure and hemorrhage in gliomas. J Neurosurg 66: 536-541, 1987.

10. Schechter J, Ahmad N, Elias K and Weiner R: Estrogen-induced tumors: Changes in the vasculature in two strains of rat. Am J Anat 179: 315-323, 1987. 
11. Meis-Kindblom JM and Kindblom LG: Angiosarcoma of soft tissue: A study of 80 cases. Am J Surg Pathol 22: 683-697, 1998.

12. Jansson L and Carlsson PO: Graft vascular function after transplantation of pancreatic islets. Diabetologia 45: 749-763, 2002.

13. Cao $Z$ and Wang $X$ : The endocrine role between $\beta$ cells and intra-islet endothelial cells. Endocr J 61: 647-654, 2014

14. Terris B, Scoazec JY, Rubbia L, Bregeaud L, Pepper MS, Ruszniewski P, Belghiti J, Flèjou J and Degott C: Expression of vascular endothelial growth factor in digestive neuroendocrine tumours. Histopathology 32: 133-138, 1998.

15. Couvelard A, O'Toole D, Turley H, Leek R, Sauvanet A, Degott C, Ruszniewski P, Belghiti J, Harris AL, Gatter K and Pezzella F: Microvascular density and hypoxia-inducible factor pathway in pancreatic endocrine tumours: Negative correlation of microvascular density and VEGF expression with tumour progression. $\mathrm{Br}$ J Cancer 92: 94-101, 2005.

16. Katayama A, Iseda I, Tone A, Matsushita Y, Inoue $\mathrm{K}$, Tsukamoto K, Yamashita H, Yamadori I, Wada J and Hida K: The usefulness of super-selective computed tomography angiography (CTA) for diagnosing and localizing a small insulinoma. Intern Med 49: 1983-1986, 2010.

17. Raymond E, Dahan L, Raoul JL, Bang YJ, Borbath I, Lombard-Bohas C, Valle J, Metrakos P, Smith D, Vinik A, et al: Sunitinib malate for the treatment of pancreatic neuroendocrine tumors. N Engl J Med 364: 501-513, 2011.

18. Asfari M, Janjic D, Meda P, Li G, Halban PA and Wollheim CB: Establishment of 2-mercaptoethanol-dependent differentiated insulin-secreting cell lines. Endocrinology 130: 167-178, 1992

19. Santos-Silva JC, Carvalho CP, de Oliveira RB, Boschero AC and Collares-Buzato CB: Cell-to-cell contact dependence and junctional protein content are correlated with in vivo maturation of pancreatic beta cells. Can J Physiol Pharmacol 90: 837-850, 2012

20. Collares-Buzato CB, Carvalho CP, Furtado AG and Boschero AC: Upregulation of the expression of tight and adherens junction-associated proteins during maturation of neonatal pancreatic islets in vitro. J Mol Histol 35: 811-822, 2004.
21. Hashizume H, Baluk P, Morikawa S, McLean JW, Thurston G, Roberge S, Jain RK and McDonald DM: Openings between defective endothelial cells explain tumor vessel leakiness. Am J Pathol 156: 1363-1380, 2000.

22. Jones HB, Reens J, Brocklehurst SR, Betts CJ, Bickerton S, Bigley AL, Jenkins RP, Whalley NM, Morgan D and Smith DM: Islets of Langerhans from prohormone convertase-2 knockout mice show $\alpha$-cell hyperplasia and tumorigenesis with elevated alpha-cell neogenesis. Int J Exp Pathol 95: 29-48, 2014.

23. Bearer EL and Orci L: Endothelial fenestral diaphragms: A quick-freeze, deep-etch study. J Cell Biol 100: 418-428, 1985.

24. Henderson JR and Moss MC: A morphometric study of the endocrine and exocrine capillaries of the pancreas. Q J Exp Physiol 70: 347-356, 1985.

25. Zanone MM, Favaro E and Camussi G: From endothelial to beta cells: Insights into pancreatic islet microendothelium. Curr Diabetes Rev 4: 1-9, 2008.

26. Lukinius A, Jansson L and Korsgren O: Ultrastructural evidence for blood microvessels devoid of an endothelial cell lining in transplanted pancreatic islets. Am J Pathol 146: 429-435, 1995.

27. Thiery JP, Acloque H, Huang RY and Nieto MA: Epithelial-mesenchymal transitions in development and disease. Cell 139: 871-890, 2009.

28. Tunggal JA, Helfrich I, Schmitz A, Schwarz H, Gunzel D, Fromm M, Kemler R, Krieg T and Niessen CM: E-cadherin is essential for in vivo epidermal barrier function by regulating tight junctions. EMBO J 24: 1146-1156, 2005.

29. Ligon LA, Karki S, Tokito M and Holzbaur EL: Dynein binds to beta-catenin and may tether microtubules at adherens junctions. Nat Cell Biol 3: 913-917, 2001.

This work is licensed under a Creative Commons Attribution-NonCommercial-NoDerivatives 4.0 International (CC BY-NC-ND 4.0) License. 